JUN 061986

\title{
Technology, Safety and Costs of Decommissioning Reference Nuclear Fuel Cycle Facilities
}

Classification of Decommissioning Wastes

$$
\text { DO MOT M.:POFILM }
$$

Prepared by H. K. Elder

Pacific Northwest Laboratory

Operated by

Battelle Memorial Institute

Prepared for

U.S. Nuclear Regulatory

Commission 


\section{DISCLAIMER}

This report was prepared as an account of work sponsored by an agency of the United States Government. Neither the United States Government nor any agency Thereof, nor any of their employees, makes any warranty, express or implied, or assumes any legal liability or responsibility for the accuracy, completeness, or usefulness of any information, apparatus, product, or process disclosed, or represents that its use would not infringe privately owned rights. Reference herein to any specific commercial product, process, or service by trade name, trademark, manufacturer, or otherwise does not necessarily constitute or imply its endorsement, recommendation, or favoring by the United States Government or any agency thereof. The views and opinions of authors expressed herein do not necessarily state or reflect those of the United States Government or any agency thereof. 


\section{DISCLAIMER}

Portions of this document may be illegible in electronic image products. Images are produced from the best available original document. 


\section{NOTICE}

This report was prepared as an account of work sponsored by an agency of the United States Government. Neither the United States Government nor any agency thereof, or any of their employees, makes any warranty, expressed or implied, or assumes any legal liability of responsibility for any third party's use, or the results of such use, of any information, apparatus, product or process disclosed in this report, or represents that its use by such third party would not infringe privately owned rights.

\section{NOTICE}

\section{Availability of Reference Materials Cited in NRC Publications}

Most documents cited in NRC publications will be available from one of the following sources:

1. The NRC Public Document Room, 1717 H Street, N.W. Washington, DC 20555

2. The Superintendent of Documents, U.S. Government Printing Office, Post Office Box 37082 , Washington, DC 20013-7082

3. The National Technıcal Information Service, Springfield, VA 22161

Although the listing that follows represents the majority of documents cited in NRC publications, it is not intended to be exhaustive.

Referenced documents available for inspection and copying for a fee from the NRC Public Docu ment Room include NRC correspondence and internal NRC memoranda; NRC Office of Inspection and Enforcement bulletins, circulars, information notices, inspection and investigation notices; Licensee Event Reports; vendor reports and correspondence; Commission papers; and applicant and licensee documents and correspondence.

The following documents in the NUREG series are available for purchase from the GPO Sales Program: formal NRC staff and contractor reports, NRC-sponsored conference proceedings, and NRC booklets and brochures. Also available are Regulatory Guides, NRC regulations in the Code of Federal Regulations, and Nuclear Regulatory Commission /ssuances.

Documents available from the National Technical Information Service include NUREG series reports and technical reports prepared by other federal agencies and reports prepared by the Atomic Energy Commission, forer unner agency to the Nuclear Regulatory Commission.

Documents available from public and special technical libraries include all open literature items, such as books, journal and periodical articles, and transactions. Federal Register notices, federal and state legislation, and congressional reports can usually be obtained from these libraries.

Documents such as theses, dissertations, foreign reports and translations, and non-NRC conference proceedings are available for purchase from the organization sponsoring the publication cited.

Single copies of NRC draft reports are available free, to the extent of supply, upon written request to the Division of Techrical Information and Document Control, U S. Nuclear Regulatory Com mission, Washington, DC 20555.

Copies of industry codes and standards used in a substantive manner in the NRC regulatory process are maintained at the NRC Library, 7920 Norfolk Avenue, Bethesda, Maryland, and are available there for reference use by the public. Codes and standards are usually copyrighted and may be purchased from the originating organization or, if they are American National Standards, from the American National Standards Institute, 1430 Broadway, New York, NY 10018. 
This report was prepared as an account of work sponsored by an agency of the United States Government. Neither the United States Government nor any agency thereof, nor any of their employees, makes any warranty, express or implied, or assumes any legal liability or responsibility for the accuracy, completeness, or usefulness of any information, apparatus, product, or process disclosed, or represents that its use would not infringe privately owned rights. Reference herein to any specific commercial product, process, or service by trade name, trademark, manufacturer, or otherwise does not necessarily constitute or imply its endorsement, recommendation, or favoring by the United States Government or any agency thereof. The views and opiniors of authors expressed herein do not necessarily state or reflect those of the United States Government or any agency thereof.
NUREG/CR-4519

PNL-5586

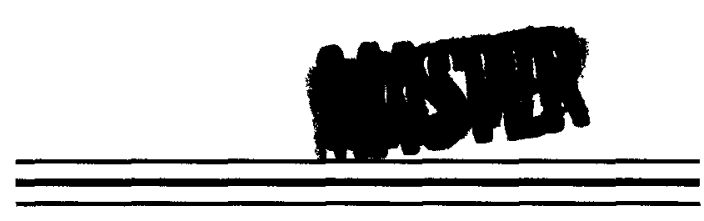

NUREG/CR--4519

TI86 011208

\title{
Technology, Safety and Costs of Decommissioning Reference Nuclear Fuel Cycle Facilities
}

\author{
Classification of Decommissioning Wastes
}

Manuscript Completed: August 1985

Date Published: May 1986

Prepared by H. K. Elder

Pacific Northwest Laboratory

Richland, WA 99352

\section{Prepared for}

Division of Engineering Technology

Office of Nuclear Regulatory Research

U.S. Nuclear Regulatory Commission

Washington, D.C. 20555

NRC FIN No. B2117 


\section{ABSTRACT}

The radioactive wastes expected to result from decommissioning nuclear fuel cycle facilities are reviewed and classified in accordance with 10 CFR 61 .

Most of the wastes from the MOX plant (exçlusive of the lagoon wastes) will require interim storage ( $11 \%$ Class A $49 \mathrm{~m}^{3} ; 89 \%$ interim storage, $\left.383 \mathrm{~m}^{3}\right)$. The MOX plant lagoon wastes are Class A waste $\left(2930 \mathrm{~m}^{3}\right)$. All of the wastes from the U-Fąb and $U_{6}$ plants are designated as Class A waste (U-Fab $1090 \mathrm{~m}^{3}, U_{6} 1259 \mathrm{~m}^{3}$ ). 


\section{CONTENTS}

ABSTRACT..................................... $i i_{i}$

FORWARD BY NUCLEAR REGULATORY COMMISSION STAFF............... vii

REFERENCES................................ viii

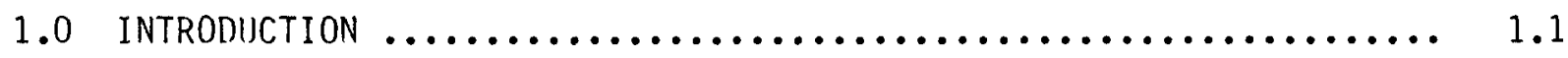

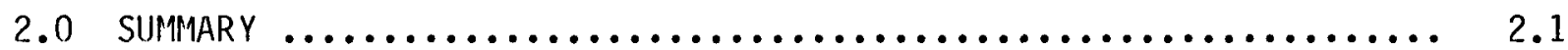

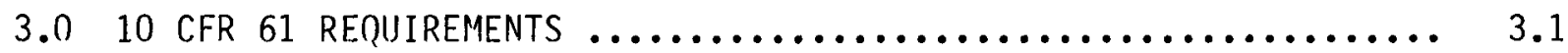

4.0 ALTERNATIVES FOR DECOMMISSIONING THE REFERENCE
FUEL CYCLE PLANTS $\ldots \ldots \ldots \ldots \ldots \ldots \ldots \ldots \ldots \ldots \ldots \ldots \ldots \ldots \ldots \ldots \ldots \ldots \ldots$

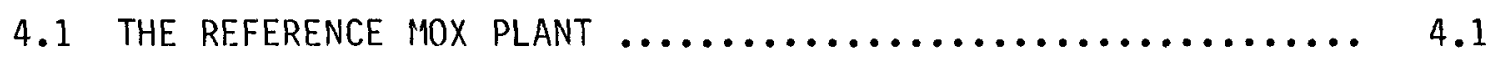

4.2 THE REFERENCE U-Fab PLANT $\ldots \ldots \ldots \ldots \ldots \ldots \ldots \ldots \ldots \ldots \ldots \ldots \ldots \ldots \ldots \ldots \ldots \ldots$

4.3 THE REFERENCE Uf ${ }_{6}$ PLANT $\ldots \ldots \ldots \ldots \ldots \ldots \ldots \ldots \ldots \ldots \ldots \ldots \ldots \ldots \ldots \ldots \ldots \ldots \ldots \ldots$

4.4 DECOMMISSIONING ALTERnATIVES $\ldots \ldots \ldots \ldots \ldots \ldots \ldots \ldots \ldots \ldots \ldots . \ldots \ldots . \ldots \ldots$

5.0 CHARACTERIZATION OF DECOMMISSIONING WASTES $\ldots \ldots \ldots \ldots \ldots \ldots \ldots \ldots \ldots$

5.1 MOX PLANT RADIOACTIVE WASTE MATERIALS ................ 5.1

5.2 U-Fab PLANT RADIOACTIVE WASTE MATERIALS $\ldots \ldots \ldots \ldots \ldots \ldots \ldots \ldots . . \ldots$

5.3 UF $_{6}$ PLANT RADIOACTIVE WASTE MATERIALS $\ldots \ldots \ldots \ldots \ldots \ldots \ldots \ldots$

6.0 CLASSIFICATION OF NUCLEAR FUEL CYCLE FACILITY

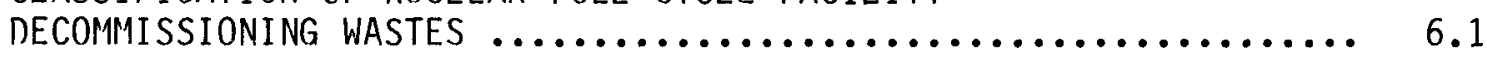

6.1 MOX PLANT DECOMMISSIONING WASTES $\ldots \ldots \ldots \ldots \ldots \ldots \ldots \ldots \ldots \ldots . . \ldots . \ldots$

6.2 U-Fab PLANT DECOMMISSIONING HASTES $\ldots \ldots \ldots \ldots \ldots \ldots \ldots \ldots \ldots \ldots . \ldots . \ldots$

6.3 UF $_{6}$ PLANT DECOMMIISSIONING WASTES $\ldots \ldots \ldots \ldots \ldots \ldots \ldots \ldots \ldots \ldots \ldots \ldots$

7.0 CONCLUSIONS $\ldots \ldots \ldots \ldots \ldots \ldots \ldots \ldots \ldots \ldots \ldots \ldots \ldots \ldots \ldots \ldots \ldots \ldots \ldots$ 


\section{TABLES}

3.1 Limiting Concentrations of Long-Lived Radionuclides Used as Bases for Waste Classification in 10 CFR $61 \ldots \ldots \ldots \ldots \ldots \ldots . . . . . . .2$

3.2 Limiting Concentrations of Short-Lived Radionuclides Used as

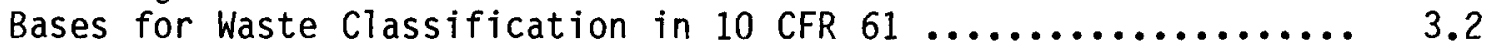

5.1 Materials from DECON at Reference MOX Plant ............... 5.2

5.2 Materials from DECON at Reference U-Fab Plant ............. 5.4

5.3 Materials from DECON at Reference $U_{6}$ Plant $\ldots \ldots \ldots \ldots \ldots \ldots \ldots$

6.1 Waste Classifications of Materials from DECON at the Reference MoX Plant ............................... 6.2

6.2 Waste Classifications of Materials from DECON at the Reference U-Fab Plant ............................. 6.3

6.3 Waste Classifications of Materials from DECON at the Reference $U_{6}$ Plant ............................. 6.4 


FORWARD
BY
NUCLEAR REGULATORY COMMISSION STAFF

The NRC staff is reappraising its regulatory position relative to the decommissioning of nuclear facilities. (1) As a part of this activity, the NRC has initiated two series of studies through technical assistance contracts. These contracts are being undertaken to develop information to support the preparation of new standards covering decommissioning.

The basic series of studies covers the technology, safety, and costs of decommissioning reference nuclear facilities. Light water reactors and fuelcycle and non-fuel-cycle facilities are included. Facilities of current design on typical sites are selected for the studies. Separate reports are prepared as the studies of the various facilities are completed.

The first report in this series covers a fuel reprocessing plant; (2) the second addresses a pressurized water reactgr; $(3)$ and the third deals with a small mixed oxide fuel fabrication plant. (4)' The fourth report, an addendum to the pressurized water reactor report, $(5)$ examines the relationship between reactor size and decommissioning cost, the cost of entombment, and the sensitivity of cost to radiation levels, contractual arrangements, and disposal site charges, The fifth report in this series deals with a low-level waste burjal ground; $(6)$ the sixth covers a large boiling water reactor power station; $(7)$ and the seventh examines a uranium fuel fabrication plant. (8) The eighth report covers non-fuel-cycle nuclear facilities. 9 ) The ninth report, an addendum to the low-level waste burial ground report, (10) supplements the description of environmental radiological surveillance programs used in the parent dofument. The tenth report deals with a uranium hexafluoride conversion plant. (1I) The eleventh report addresses the decommissioning of nuclear reactors at multiplereactor power stations. (12) The twelfth report covers nuclear research and test reactors. $(13)$ The thirteenth report examines the decommissioning of reference ljght water reactors that have been involved in serious

accidents. (14) The fourteenth and fifteenth reports are addendums to the pressurized water reactor report and the boiling water reactor report, respectively, and examine the impacts on decommissioning of both of these plant types of a temporacy inability to dispose of waste offsite at the time of decommissioning. $(15,16)$ The sixteenth report, an addendum to the nuclear Research and test reacfors report, addresses the sensitivity of decommissioning radiation facilities. (17) The seventeenth report deals with the decommissioning of independent spent fuel storage installations. (18) The eighteenth report coverspost-accident decommissioning at fuel cycle and non-fuel cycle facilities. (19) The nineteenth report is an addendum to the multiple reactor power station report and examines the effects on decommissioning of interim inability to dispose of wastes offsite at a multiple-reactor power station. (20) Additional addendums to the pressurized and boiling water reactor reports classify the wasfes from PWR and BWR decommissioning in accordance with 10 CFR $61 .(21,22)$ This report examines the radioactive wastes expected to 
result from decommissioning reference fuel cycle facilities that have been covered in previous reports $(4,8,11)$, and classifies those wastes in accordance with 10 CFR 61.

The second series of studies covers supporting information on the decommissioning of nuclear facilities. Four reports have been issued in the second series. The first consists of an annotated bibliography on the decommissioning of nuclear facilities. (23) The second is a review and analysis of current decommissioning regulations. (24) The third covers the facilitation of the decommissioning of 1 ight water reactors. 25$)$ The fourth report covers the establishment of an information base concerning monitoring for compliance with decommissioning survey criteria. ${ }^{26)}$ The fifth report addresses the technology and cost of termination surveys associated with decommissianing of nuclear facilities. (27)

The information provided in this report on decommissioning of a pressurized water reactor, including any comments, will be included in the record for consideration by the Commission in establishing criteria and new standards for decommissioning. Comments on this report should be mailed to

Chief

Chemical Engineering Branch

Division of Engineering Technology

Office of Nuclear Regulatory Research

U.S. Nuclear Regulatory Commission

Washington, D.C. 20555

\section{REFERENCES}

1. Plan for Reevaluation of NRC Policy on Decommissioning of Nuclear Facilities. NUREG-0436, REV. 1, Office of Standards Development, U.S. Nuclear Regulatory Commission, December 1978.

2. Technology, Safety and Costs of Decommissioning a Reference Nuclear Fuel Reprocessing Plant. NUREG-0278, Pacific Northwest Laboratory for U.S. Nuclear Regulatory Commission, October 1977.

3. Technology, Safety and Costs of Decommissioning a Reference Pressurized Water Reactor Power Station. NUREG/CR-0130, Pacific Northwest Laboratory for U.S. Nuclear Regulatory Commission, June 1978.

4. Technology, Safety and Costs of Decommissioning a Reference Small Mixed oxide Fuel Fabrication Plant. NUREG/CR-0129, Pacific Northwest Laboratory for U.S. Nuclear Regulatory Commission, February 1979.

5. Technology, Safety and Costs of Decommissioning a Reference Pressurized Water Reactor Power Station. NUREG/CR-0130 Addendum, Pacific Northwest Laboratory for U.S. Nuclear Regulatory Commission, August 1979. 
6. Technology, Safety and Costs of Decommissioning a Reference Low-Level Waste Burial Ground. NUREG/CR-0570, Pacific Northwest Laboratory for U.S. Nuclear Regulatory Commission, June 1980.

7. Technology, Safety and Costs of Decommissioning a Reference Boiling Water Reactor Power Station. NUREG/CR-0672, Pacific Northwest Laboratory for U.S. Nuclear Regulatory Commission, June 1980.

8. Technology, Safety and Costs of Decommissioning a Reference Uranium Fuel Fabrication Plant. NUREG/CR-1266, Pacific Northwest Laboratory for U.S. Nuclear Regulatory Commission, October 1980.

9. Technology, Safety and Costs of Decommissioning Reference Non-Fuel-Cycle Nuclear Facilities. NUREG/CR-1754, Pacific Northwest Laboratory for U.S. Nuclear Regulatory Commission, February 1981.

10. Technology, Safety and Costs of Decommissioning a Reference Low-Level Waste Burial Ground. NUREG/CR-0570 Addendum, Pacific Northwest Laboratory for U.S. Nuclear Regulatory Commission, May 1981.

11. Technology, Safety and Costs of Decommissioning a Reference Uranium Hexafluoride Conversion Plant. NUREG/CR-1757, Pacific Northwest Laboratory for II.S. Nuclear Regulatory Commission, October 1981.

12. Technology, Safety and Costs of Decommissioning Nuclear Reactors at MuTtiple-Reactor Stations. NUREG/CR-1755, Pacific Northwest Laboratory for U.S. Nuclear ReguTatory Commission, January 1982.

13. Technology, Safety and Costs of Decommissioning Reference Nuclear Research and Test Reactors. NUREG/CR-1756, Pacific Northwest Laboratory for U.S. Nuclear Regulatory Commission, March 1982.

14. Technology, Safety and Costs of Decommissioning Reference Light Water Reactors Following Postulated Accidents. NUREG/CR-2601, Pacific Northwest Laboratory for U.S. Nuclear Regulatory Commission, November 1982.

15. Technology, Safety and Costs of Decommissioning a Reference Pressurized Water Reactor Power Station. NUREG/CR-0130 Addendum 2, Pacific Northwest Laboratory for U.S. Nuclear Regulatory Commission, June 1983.

16. Technology, Safety and Costs of Decommissioning a Reference Boiling Water Reactor Power Station. NUREG/CR-0672 Addendum 1, Pacific Northwest Laboratory for U.S. Nuclear Regulatory Commission, June 1983.

17. Technology, Safety and Costs of Decommissioning Reference Nuclear Research and Test Reactors. NUREG/CR-1756 Addendum, Pacific Northwest Laboratory for U.S. Nuclear Regulatory Commission, July 1983.

18. Technology, Safety and Costs of Decommissioning Reference Independent Spent Fuel Storage Installations. NUREG/CR-2210, Pacific Northwest Laboratory for U.S. Nuclear Regulatory Commission, January 1984. 
19. Technology Safety and Costs of Decommissioning Reference Nuclear Fuel Cycle and Non Fuel Cycle Facilities Following Postulated Accidents NUREG/CR-3293, Pacific Northwest Laboratory for U.S. NRC, May 1985.

20. Technology, Safety, and Costs of Decommissioning Nuclear Reactors at MuTtiple-Reactor Stations. NUREG/CR-1755 Addendum 1, Pacific Northwest Laboratory for U.S. Nuclear Regulatory Commission, April 1985.

21. Technology, Safety and Costs of Decommissioning a Reference Pressurized Water Reactor Power Station - Classification of Decommissioning Wastes. NUTREG/CR-0130, Addendum 3, Pau. Fic Northwest Laboratory for U.S. NucTear Regulatory Commission, September 1984.

22. Technology, Safety and Costs of Decommissioning a Reference Boiling Water Reactor Power Station - Classification of Decommissioning Wastes. NUREG/CR-0672, Addendum 2, Pacific Northwest Laboratory for U.S. Nuclear Regulatory Commission, September 1984.

23. Decommissioning of Nuclear Facilities - An Annotated Bibliography. NUREG/CR-0130, Pacific Northwest Laboratory for U.S. Nuclear Regulatory Commission, August 1979.

24. Decommissioning of Nuclear Facilities - A Review and Analys is of Current Regulations. NUREG/CR-0671, Pacific Northwest Laboratory and BattelTe Human Affairs Research Centers for II.S. Nuclear Regulatory Commission, August 1979.

25. Facilitation of Decommissioning of Light Water Reactors. NUREG/CR-0569, Pacific Northwest Laboratory for U.S. Nuclear Regulatory Commission, December 1979.

26. Monitoring for Compliance with Decommissioning Termination Survey Criteria. NUREG/CR-2082, Oak Ridge National Laboratory for U.S. Nuclear Regulatory Commission, June 1981.

27. Technology and Cost of Termination Surveys Associated with Decommissioning of Nuclear Facilities. NUREG/CR-2241, nak Ridge National Laboratory for U.S. Nuclear Regulatory Commission, February 1982. 


\subsection{INTRODUCTION}

In the analysis of the decommissioning of the reference fuel $\left(c_{y}\right)$ le
facilities reported previously in NUREG/CR-01290(I) NUREG/CR-1266 NUREG/CR-1757, 3 ) it was assumed that all of the low-level radioactive waste from decommissioning could be disposed of by land disposal at licensed shallowland burial grounds. The purpose of this addendum is to examine this assumption of waste suitability for shallow-land burial by classifying the decommissioning wastes from the reference plant studies in terms of waste classes defined in Title 10, Part 61 of the Code of Federal Regulations (10 CFR 61). This information is intended for use by the Nuclear Regulatory Commission (NRC) as background data and bases in the modification of existing regulations and the development of new regulations pertaining to decommissioning activities. This report should also be helpful to fuel cycle plant operators in estimating decommissioning waste management costs and to burial ground operators in planning for the land burial of decommissioning wastes.

By Federal Register natice dated December $27,1982,(4)$ the NRC promulgated a new regulation (10 CFR 61) governing the land disposal of low-level radioactive waste (LLW). This new regulation establishes three classes of LLW, based on radiological hazard, and provides minimum waste form and stability requirements and near-surface disposal requirements for the land burial of these wastes. Wastes with radionuclide concentrations that do not meet the classification criteria of 10 CFR 61 are generally unacceptable for routine near-surface disposal. Licenses are required to safely store these wastes until a specific determination can can be made on their disposition.

The principal results of this analys is of classification of decommissioning wastes from the reference plant are summarized in Section 2. A summary of waste classification requirements from 10 CFR 61 is given in Section 3 . The decommissioning alternatives evaluated in the reference MOX plant study are briefly summarized in Section 4. Information on quantities and radionuclide contents of the radioactive wastes from decommissioning the reference MOX plant is presented in Section 5. The classification of these wastes in terms of the waste classes defined in 10 CFR 61 is presented in Section 6 . Conclusions and recommendations are given in Section 7 . 


\subsection{SUMMARY}

In the analysis of the decommissioning of reference nuclear fuel cycle facilities reported previously in NUREG/CR-1266, NUREG/CR-0129 and NUREG/CR-1757, it was assumed that the surface burial at a licensed shallowland burial ground was acceptable. The purpose of this addendum is to reevaluate this assumption in terms of the recently established requirements for waste characterization published in Title 10, Part 61 of the Code of Federal Regulations (10 CFR 61). To accomplish this reevaluation, radioactive wastes from the conceptual decommissioning of the reference plants are classified in terms of the waste classes specified in Section 61.55 of 10 CFR. Section 61.55 establishes three classes of low-level radioactive waste (LLW) based on radiological hazard, and defines limiting concentrations of long-lived and short-lived nuclides for each waste class. Minimum waste form and stability requirements are also defined for each waste class.

Class $A$ waste has the lowest concentrations of radioactivity and must meet minimum requirements for burial designed to facilitate handling at the disposal site and provide protection of the health and safety of burial site personne1. Class B waste has higher concentrations of radioactivity and must meet more rigorous requirements on waste form to ensure stability after disposal. Class $C$ waste must not only meet more rigorous requirements on waste form to ensure stability but also requires additional measures at the disposal facility to protect against inadvertent intrusion. Wastes with radionuclide concentrations that do not meet the classification criteria of 10 CFR 61 are generally unacceptable for routine near-surface disposal and must be safely stored by the licensee until a specific determination can be made on their disposition.

Radioactive materials that require disposal as a consequence of conceptual decommissioning of the reference facilities include 1) contaminated materials, and 2) radioactive wastes.

Contaminated materials from decommissioning fuel cycle plants include nearly all of the piping and equipment in the plant buildings and facilities, as well as many of the concrete surfaces of these buildings. The principal limiting isotopes in these materials are plutonium in the MOX plant and uranium in the U-Fab and $U_{6}$ plants. Average concentrations of limiting radionuclides in contaminated materials are low enough that these materials constitute Class $A$ waste for the U-Fab and UF 6 plants. For the MOX plant, most of the waste from decommissioning will have to be sent to interim storage due to the high content of long-lived isotopes.

Radioactive wastes from decommissioning operations include both wet solid wastes and dry solid wastes for the MOX plant. Wet solid wastes are the solidified wastes that result from the processing of chemical decontamination solutions. Dry solid wastes include discarded contaminated materials such as rags and wipes, plastic sheeting, contaminated tools, and anti-contamination clothing. Most of the radioactive waste from decommissioning operations can be classified as Class A waste. 
The alternative approaches to decommissioning nuclear facilities considered in the reference studies are DECON (immediate decontamination to unrestricted release), SAFSTOR (safe storage with deferred decontamination to unrestricted release), and ENTOMB (entombment of radioactive materials with decay to unrestricted release) only for the MOX plant. The DECON alternative results in a greater quantity of radioactive waste being generated, and requires a greater commitment of disposal site space than either of the other two decommissioning alternatives. Only the DECON alternative is considered in this study because it is the only significant alternative for fuel cycle plants where no advantage is realized by storage due to the long life of the significant radionuclides.

All of the radioactive waste from $U-F a b$ and $U_{6}$ plant decommissioning can be classified as Class A waste. To be acceptable for shallow-land disposal, this waste must meet the minimum packaging and waste form requirements given in 10 CFR 61.56(a).

Most of the MOX plant waste is considered to have concentrations of the long-lived isotopes that exceed the Class $C$ waste requirement and will have to be placed in interim storage. 


\section{$3.0 \quad 10$ CFR 61 REOUIREMENTS}

By Federal Register Notice dated December $27,1982,(4)$ the NRC amended its regulations to provide specific requirements for iicensing the land disposal of low-level radioactive wastes containing source, special nuclear, or byproduct material. The majority of these requirements are contained in a new Part 61 to Title 10 of the Code of Federal Regulations (10 CFR 61), "Licensing Requirements for Land Disposal of Radioactive Waste," which took effect on January 23, 1983. Some additional requirements directed primarily at waste generators and handlers were concurrently published as a new Section 20.311 of part 20, "Standards for Protection Against Radiation." The effective date of 10 CFR 20.311 is December 27, 1983.

Although the new requirements apply primarily to disposal site operators, they also include provisions that pertain to persons who generate waste that will be disposed of at land disposal facilities. Licensees generating waste have a responsibility to determine the presence and concentrations of various nuclides listed in Section 61.55, and thereby to classify the waste. Packaging and waste stability requirements for waste destined for shallow-land burial depend on the waste classification. Wastes that do not meet the classification requirements of Section 61.55 require special provisions for their disposal and would, in most instances, require interim storage pending identification of a suitable disposal alternative.

Section 61.55 defines radioactive waste suitable for land disposal as falling into one of three categories, i.e., Class A waste, Class B waste, and Class $C$ waste. Wastes are determined to fall into one of these classes by comparison to limiting concentrations of particular long-lived and short-lived radionuclides. Class $A$ waste contains the lowest radionuclide concentrations and must meet only minimum waste form requirements. Class $B$ and $C$ wastes contain higher radionuclide concentrations and must meet both the minimum waste form and the stability requirements of Section 61.56 . Class $C$ waste must be disposed of by use of methods that provide added protection against inadvertent intrusion into the burial ground.

The basis for classification of LLW in terms of long-lived radionuclide concentrations is shown in Table 3.1, reproduced from Table 1 of 10 CFR 61.55. The basis for classification of LLW in terms of short-lived radionuclide concentrations is shown in Table 3.2, reproduced from Table 2 of 10 CFR 61.55.

If the radioactive waste contains only radionuclides listed in Table 3.1 (long-lived radionuclides), classification is determined using the following guidelines. If the concentration does not exceed 0.1 times the value in the table, the waste is Class $A$. If the concentration exceeds 0.1 times the value in Table 3.1 but does not exceed the value in the table, the waste is $\mathrm{Class} C$. If the concentration exceeds the value in Table 3.1 , the waste is generally unacceptable for near-surface disposal. For example, for Class $A$ wastes the limiting concentration of long-lived alpha-emitting transuranic 
TABLE 3.1. Limiting Concentrations of Long-Lived Radionuclides Ised as Bases for Waste Classification in 10 CFR 61 (a)

\begin{tabular}{|c|c|}
\hline Radionuclide & $\begin{array}{l}\text { Concentration } \\
\left(\text { curies } / \mathrm{m}^{3}\right)\end{array}$ \\
\hline $\begin{array}{l}14 \mathrm{C} \\
14 \mathrm{C} \text { in activated metal } \\
59 \mathrm{Ni} \text { in activated metal } \\
94 \mathrm{Nb} \text { in activated metal } \\
99_{\mathrm{TC}} \\
129 \mathrm{I}\end{array}$ & $\begin{array}{l}8 \\
80 \\
220 \\
0.2 \\
3 \\
0.08\end{array}$ \\
\hline $\begin{array}{l}\text { Alpha-emitting transuranic } \\
\text { nuclides with half-life } \\
\text { greater than five years }\end{array}$ & $100^{(b)}$ \\
\hline $\begin{array}{l}241 \mathrm{Pu} \\
{ }_{242} \mathrm{Cm}\end{array}$ & $\begin{aligned} 3 & 500^{(\mathrm{b})} \\
20 & 000^{(\mathrm{b})}\end{aligned}$ \\
\hline
\end{tabular}

(a) Reproduced from Table 1 of 10 C.FR 61.55.

(b) Units are nanocuries per gram.

TABLE 3.2. Limiting Concentrations of Short-Lived Radionucljides Used as Bases for Waste Classification in 10 CFR 61 (a)

\begin{tabular}{|c|c|c|c|}
\hline \multirow[b]{2}{*}{ Radionuclide } & \multicolumn{3}{|c|}{ Concentration (curies $/ \mathrm{m}^{3}$ ) } \\
\hline & $\begin{array}{c}\text { Column } \\
1\end{array}$ & $\begin{array}{c}\text { Column } \\
2\end{array}$ & $\begin{array}{c}\text { CoTumn } \\
3\end{array}$ \\
\hline $\begin{array}{l}\text { Total of all nuclides with half- } \\
\text { life less than five years }\end{array}$ & 700 & (b) & (b) \\
\hline $\begin{array}{l}{ }^{3} \mathrm{H} \\
60^{\mathrm{Co}} \\
63 \mathrm{Ni} \\
63_{\mathrm{Ni}} \text { in activated metal } \\
90 \mathrm{Sr} \\
137 \mathrm{Cs}\end{array}$ & $\begin{array}{r}40 \\
700 \\
3.5 \\
35 \\
0.04 \\
1\end{array}$ & $\begin{array}{r}\text { (b) } \\
\text { (b) } \\
70 \\
700 \\
150 \\
44\end{array}$ & $\begin{array}{ll} & (\mathrm{b}) \\
& (\mathrm{b}) \\
& 700 \\
7 & 000 \\
7 & 000 \\
4 & 600\end{array}$ \\
\hline
\end{tabular}

(a) Reproduced from Table 2 of 10 CFR 61.55.

(b) There are no limits established for these radionuclides in $C$ Class $R$ or $C$ waste. Practical considerations such as the effects of external radiation and internal heat generation on transportation, handling, and disposal will limit the concentrations for these wastes. These wastes shall be $\mathrm{Cl}$ ass $\mathrm{B}$ unless the concentrations of other nuclides in Table 3.2 determine the waste to be $\mathrm{Class} \mathrm{C}$ independent of these nuclides. 
nuclides is $10 \mathrm{nCi} / \mathrm{gram}$. For Class $\mathrm{C}$ wastes, the disposal limit for transuranic waste is set at $100 \mathrm{nCi} / \mathrm{gram}$.

If the radioactive waste contains only radionuclides listed in Table 3.2 (short-lived radionuclides), classification is determined using the following guidelines. If the concentration does not exceed the value in column 1 , the waste is $\mathrm{Class} A$. If the concentration exceeds the value in Column 1 but does not exceed the value in Column 2, the waste is Class $B$. If the concentration exceeds the value in Column 2 but does not exceed the value in column 3 , the waste is $\mathrm{Class} C$. If the concentration exceeds the value in Column 3 , the waste is generally acceptable for near-surface disposal.

If radioactive waste does not contain any of the radionuclides in either Table 3.1 or lable 3.2 , it is Class $A$.

If radioactive waste contains a mixture of both long-lived and short-lived nuclides, some of which are listed in Table 3.1 and some in Table 3.2 , the waste classification is determined in the following manner. If the concentration of a nuclide listed in Table 3.1 does not exceed 0.1 times the value given in Table 3.1, the class is determined by the concentration of nuclides listed in Table 3.2. If the concentration of a nuclide listed in Table 3.1 exceeds 0.1 times the value listed in Table 3.1 but does not exceed the value in Table 3.1, the waste is Class $C$, provided the concentration of nuclides listed in Table 3.2 does not exceed the values shown in Column 3 of Table 3.2 .

For determining the classification of waste that contains a mixture of radionuclides, the sum-of-fractions rule described in 10 CFR 61.55(a)(7) is used. To use the sum-of-fractions rule, it is necessary to divide each nuclide's concentration by the appropriate limit and add the resulting values. The appropriate limits must all be taken from the same column of the same table. The sum of the fractions for the column must be less than 1.0 if the waste class is to be determined by that column.

The NRC has prepared a technical position $(5)$ describing procedures acceptable to the regulatory staff which may be used by licensees to determine the presence and concentrations of radionuclides listed in Table 3.1 and Table 3.2, thereby classifying wastes for near-surface disposal. The basic methods for identifying radionuclide concentrations in nuclear waste include the following:

- materials accountability

- classification by source

- gross radioactivity measurements

- direct measurement of individual radionuclides.

Materials accountability refers to the process whereby a given quantity (and resulting concentration) of radioactive material may be known to be contained within a given waste, or may be inferred by determining the difference between the quantities of radioactive material entering and exiting a particular process. Classification by source is similar to materials accountability and involves determining the radionuclide content and classification of waste through knowledge and control of its source. Gross radioactivity measurement 
entails the establishment of a program to correlate specific radionuclide concentrations in the waste with gross measurements of radioactivity levels. Radionuclide concentrations may also be measured directly or may be inferred by ratioing the concentrations of radioisotopes that can be readily measured.

The NRC technical position (5) also provides guidance on determining the waste volumes to be used in calculating radionuclide concentrations. In many cases the volume used for waste classification purposes may be taken to be the volume of the waste container. This would be true of trash waste streams compacted into shipping containers. If a particular waste is stabilized within a waste container using a solidification medium such as cement or bitument, the classification volume may be considered to be the volume of the solidified mass. The waste classification volume of large unpackaged components such as contaminated pumps, heat exchangers, etc., may be taken to be the overall volume of the component.

If the volume of the waste container is significantly larger (i.e., more than $10 \%$ larger) than the volume of the contaminated waste, the volume used for classification purposes should be that of the waste. For example, for wastes such as ion exchange resins or filter media contained within a disposable demineralizer or liner, the volume used for waste classification should be the volume of the continued waste rather than the gross volume of the container. For neutron-activated materials such as the reactor pressure vessel or the vessel internals that are cut into sections and package for disposal, the volume for waste classification should be the full-density volume of the material (i.e., the weight divided by the density) rather than the container volume.

Section 10 CFR $61.55(a)(8)$ states that in determining radionuclide concentrations in nuclear waste, the concentrations may be averaged over the volume of the waste, or over the weight if the concentration units are expressed in nanocuries per gram. In the averaging process, consideration should be given to 1) whether the distribution of radionuclides within the waste can be considered to be reasonably homogeneous, and 2) whether the volume of the waste container is significantly larger than the volume of the waste itself and the differential volume consists largely of void space. Most waste forms may be considered homogeneous for purposes of waste classification. Example of homogeneous wastes include spent ion exchange resins, filter media, solidified liquids, contaminated dirt, contaminated concrete, and contaminated trash when compacted in waste containers. 


\subsection{ALTERNATIVES FOR DECOMMISSIONING THE REFERENCE FUEL CYCLE PLANTS}

The quantities and curie contents of the radioactive wastes from decommissioning depend on several factors, including the operating history, decontamination activities performed during the operating 1 ife, and the alternative chosen for decommissioning. Three decommissioning alternatives, DECON, SAFSTOR, and ENTOMB, are analyzed in the reference study of MOX plant decommissioning. For $U_{\text {Eab }}$ and $U_{6}$ plants, DECON and SAFSTOR are covered in the reference studies. These decommissioning alternatives are briefly described in this section. The characteristics of the radioactive wastes that result when each alternative is conceptually applied to the decommissioning of the reference plants are summarized in Section 5 .

\subsection{THE REFERENCE MOX PLANT}

The reference small mixed oxide fuel fabrication plant (1) is designed for the production of $(\mathrm{U}-\mathrm{Pu}) \mathrm{O}_{2}$ fuel pellets and incorporation of these pellets into clad fuel rods. The plant uses a head-end process involving blending of plutonium and uranium solutions followed by coprecipitation and calcination to form mixed oxide fuel. The annual operating capacity of the plant is 2.3 metric tons of mixed oxide fuel to produce 12,750 mixed oxide fuel pins per year containing 144 pellets in each fuel pin. Each fuel pellet weights 1.25 grams.

\subsection{THE REFERENCE U-Fab PLANT}

The Wilmington, North Carolina, plant of General Electric Company(2) is the reference facility for this study. The Wilmington plant currently uses two head-end processes for converting gaseous $\mathrm{UF}_{6}$ to $\mathrm{UO}_{2}$. The primary method used is a chemical process involving hydrolysis of vaporized UF 6 to ammonium diuranate (ADU) precipitate using ammonia, and reduction and calcining of the ADU to dry $\mathrm{UO}_{2}$ powder. The secondary method involves direct conversion of UF 6 vapor to $\mathrm{U}_{3} \mathrm{O}_{8}$ in a flame conversion reactor and reduction of $\mathrm{U}_{3} \mathrm{O}_{8}$ to $\mathrm{UO}_{2}$ powder in a reduction-calciner.

Details of the reference U-Fab plant, the plant process descriptions and site description details are given in Reference 2 .

\subsection{THE REFERENCE UF 6 PLANT}

The reference $U F_{6} \mathrm{plant}^{(3)}$ is assumed to be operated for 40 years at a production rate of 10,000 metric tons of natural uranium per year. The feed to the $\mathrm{plant}$ is natural uranium $\mathrm{U}_{3} \mathrm{O}_{8}$ (yellowcake). Yellowcake concentrate extracted from uranium ore is converted to the volatile compound uranium hexafluoride $\left(U_{6}\right)$ for enrichment by the gaseous diffusion process. Two processes are used which differ primarily in the method of purification of the product. 
The purification step is added either at the beginning using a solvent extraction process or at the end by a fractional distillation of the UF 6 . The reference plant employs the wet chemical solvent extraction step at the head end of the process to prepare a high-purity uranium feed to the reduction, hydrofluorination, and fluorination steps. The effluents consist of impurities contained as dissolved solids in the solvent extraction waste stream. The second waste stream, fluoride waste, is generated primarily by the hydrofluorination system. Solvent extraction and fluoride wastes are entrapped in waste lagoons onsite.

\subsection{DECOMMISSIONING ALTERNATIVES}

The alternative approaches to decommissioning the reference plants that are considered in the reference study are DECON (immediate decontamination to unrestricted release), SAFSTOR (safe storage with deferred decontamination to unrestricted release), and ENTOMB (entombment of radioactive materials with decay to unrestricted release). $(6,7)$ These alternatives can be defined as follows.

DECON is the prompt removal from the facility and site of all materials with residual radioactivity levels greater than those permitted for unrestricted use of the property. DECON meets the requirements for termination of the facility license and, under present regulatory requirements, is the only decommissioning alternative that renders the facility and site available for unrestricted use within a short time period. DECON requires the removal of all equipment, structures, and site materials that are radioactively activated or contaminated to levels greater than acceptable residual contamination levels. This alternative results in a greater quantity of radioactive waste being generated for offsite disposal and requires a greater commitment of disposal site space than either of the other two decommissioning alternatives.

SAFSTOR comprises those activities required to prepare and maintain the facility in a condition that poses an acceptable risk to the public and safely stores the property for a period to allow some decay of the onsite radioactivity, followed by decontamination of the facility to an unrestricted level. SAFSTOR includes three phases of activity: 1) preparations for safe storage, 2) safe storage, and 3) deferred decontamination. Preparations for safe storage include comprehensive cleanup and decontamination activities sufficient to allow shutdown of all plant systems and installation of security barriers and remotely monitored surveillance devices. Preparations for safe storage are followed by a period of continuing care (safe storage) to permit some decay of the residual radioactivity. Requirements during the continuing-care period include activities to maintain the structural integrity and prevent intrusion into the facility. Since materials having radioactivity levels above unrestricted release levels are still onsite, an amended nuclear license remains in force until the deferred decontamination is complete. At the conclusion of the safe storage period, deferred decontamination is accomplished to remove from the site any materials with residual radioactivity greater than that permitted for release of the property for unrestricted use. 
ENTOIA is the encasement and maintenance of nonreleasable radioactive materials in a monolithic structure of concrete or other structural material with long-term surveillance until the radioactivity has decayed to levels suitable for unrestricted use. The structure should be sufficiently strong and long-lived to ensure retention of the radionuclides during the long-term surveillance period. 


\subsection{CHARACTERIZATION OF DECOMMISSIONING WASTES}

Information on waste volumes, curie contents, and major radionuclides in the wastes from decommissioning the reference plants are given in References 1 , 2 and 3. Waste characterization data derived from the reference plants are summarized in this section to provide a basis for the waste classification discussion of Section 6 .

\subsection{MOX PLANT RADIOACTIVE WASTE MATERIALS} include:

Radioactive wastes generated during the DECON of a small MOX plant

- solidified liquids from chemical decontamination activities

- contaminated process equipment, tanks, glove boxes, and piping

- concrete rubble from the mechanical decontamination of contaminated floors and walls

- HEPA and roughing filters

- sections of ventilation ductwork

- combustible and noncombustible trash (protective clothing, contaminated tools, rags, paper, plastic, metal scrap, etc.)

- possibly, sludge from the sewage lagoons.

The bulk of the material that must be packaged for disposal will be contaminated with plutonium and uranium

Table 5.1 provides a summary of data on burial volumes, radioactivity (curie) contents, and fractional radioactivities of limiting short-lived radionuclides for contaminated materials from DECON at the reference MOX plant. Data on burial volumes are from Table 10.1.5 of Reference 1. Data on curie contents are from Table 10.1.6 of Reference 1. Data on fractional radioactivities of limiting short-lived radionuclides are from Table 10.1 .7 of Reference 1.

\subsection{U-Fab PLANT RADIOACTIVE WASTE MATERIALS}

Radioactive wastes generated during DECON of the U-Fab plant include:

- contaminated process equipment, tanks, hoods, and piping 
TABLE 5.1. Materials from DECON of Reference MOX Plant

\begin{tabular}{|c|c|c|c|c|c|c|}
\hline \multirow[b]{2}{*}{ Component } & \multirow[b]{2}{*}{ Material } & \multirow[b]{2}{*}{$\begin{array}{l}\text { Radi oactivity } \\
\text { (Ci) } \\
\end{array}$} & \multirow[b]{2}{*}{$\begin{array}{c}\text { Burial Volume } \\
\left(\mathrm{m}^{3}\right)\end{array}$} & \multirow[b]{2}{*}{$\mathrm{Ci} / \mathrm{m}^{3}$} & \multicolumn{2}{|c|}{$\begin{array}{c}\text { Fractional Radioactivity } \\
\text { of Limiting Long-Lived } \\
\text { Nuclides }\end{array}$} \\
\hline & & & & & $241 \mathrm{pu}$ & $\begin{array}{l}\text { Greater than } \\
5 \text { year } \\
\text { Half Life } \\
\end{array}$ \\
\hline $\begin{array}{r}\text { Glove Boxes } \\
\text { and Hoods }\end{array}$ & $\begin{array}{l}\text { Stainless } \\
\text { Steel and } \\
\text { Plastic }\end{array}$ & 13449 & 134.8 & 99.7 & $1.7 \times 10^{-3}$ & 0.983 \\
\hline $\begin{array}{l}\text { Tanks and } \\
\text { Equipment }\end{array}$ & Steel & 4100 & 108.2 & 37.9 & $1.7 \times 10^{-3}$ & 0.983 \\
\hline $\begin{array}{l}\text { HEPA and Rough- } \\
\text { ing Filters }\end{array}$ & $\begin{array}{l}\text { Filter } \\
\text { Materials }\end{array}$ & 1098 & 34.3 & 32.0 & $1.7 \times 10^{-3}$ & 0.983 \\
\hline Concrete Rubble & Concrete & 979 & 20.0 & 48.9 & $1.7 \times 10^{-3}$ & 0.983 \\
\hline $\begin{array}{l}\text { Solidified Decon } \\
\text { Liquids }\end{array}$ & $\begin{array}{l}\text { Concrete and } \\
\text { Sludge }\end{array}$ & 23496 & 14.4 & 1631.7 & $1.7 \times 10^{-3}$ & 0.983 \\
\hline Trash & Miscellaneous & 0.4 & 48.6 & $8.2 \times 10^{-3}$ & $1.7 \times 10^{-3}$ & 0.983 \\
\hline $\begin{array}{l}\text { Piping Valves } \\
\text { and Ductwork }\end{array}$ & Steel & 4368 & 71.0 & 61.5 & $1.7 \times 10^{-3}$ & 0.983 \\
\hline $\begin{array}{l}\text { Sewage Lagoon } \\
\text { Sludge }\end{array}$ & $\begin{array}{l}\text { Sludge and } \\
\text { Soil } 1\end{array}$ & 0.5 & 2930 & $1.7 \times 10^{-4}$ & $1.7 \times 10^{-3}$ & 0.983 \\
\hline
\end{tabular}


- concrete rubble from the mechanical decontamination of contaminated floors and walls

- HEPA and roughing filters

- sections of ventilation ductwork

- combustible and noncombustible trash (protective clothing, contaminated tools, rags, paper, plastic, metal scrap, etc.)

- sludge, liners, and soil from the waste treatment lagoons.

Table 5.2 provides a summary of data on burial volumes, radioactivity (curie) contents, and fractional radioactivities of limiting short-lived radionuclides for contaminated materials from DECON at the reference U-Fab plant. Data on burial volumes are from Table 10.1 .5 of Reference 1. Data on curie contents are from Table 7.4.1 of Reference 2 .

\subsection{UFG PLANT RADIOACTIVE WASTE MATERIALS $_{6}$} include:

Radioactive wastes generated during DECON of the reference $U_{6}$ plant

- contaminated process equipment, tanks, and piping

- concrete rubble from the mechanical decontamination of contaminated floors and walls

- HEPA and roughing filters

- sections of ventilation ductwork

- combustible and noncombustible trash (protective clothing, contaminated tools, rags, paper, plastic, metal scrap, etc.)

- sludge, liners, and soil from the waste lagoons.

All of the material that must be packaged for disposal will be contaminated with uranium.

Table 5.3 provides a summary of data on burial volumes, radioactivity (curie) contents, and fractional radioactivities of limiting short-lived radionuclides for contaminated material from DECON at the reference UF 6 plant. Data on burial volumes are from Table 10.1 .5 of Reference 3. Data on curie contents are from Table 7.4.1 and 7.4.2 of Reference 3 . 
TABLE 5.2. Materials from DECON of Reference U-Fab Plant

\begin{tabular}{|c|c|c|c|c|c|}
\hline Component & Material & $\begin{array}{c}\text { Radioactivity } \\
\text { (Ci) }\end{array}$ & $\begin{array}{c}\text { Burial Volume } \\
\left(\mathrm{m}^{3}\right)\end{array}$ & $\mathrm{Ci} / \mathrm{m}^{3}$ & $\begin{array}{l}\text { Fractional } \\
\text { Radi oactivity } \\
\text { of Limiting } \\
\text { Long-Lived } \\
\text { Nuclides } \\
\text { Greater than } \\
5 \text { year } \\
\text { Half Life } \\
\end{array}$ \\
\hline Hoods, Equi pment & Steel & $8.9 \times 10^{-3}$ & 764.4 & $1.2 \times 10^{-5}$ & 1.0 \\
\hline Pipe & Steel & $4.3 \times 10^{-4}$ & 118.5 & $3.6 \times 10^{-6}$ & 1.0 \\
\hline Filters & $\begin{array}{l}\text { Filter } \\
\text { Material }\end{array}$ & $6.8 \times 10^{-4}$ & 51.7 & $1.3 \times 10^{-5}$ & 1.0 \\
\hline Concrete Rubble & Concrete & $8.6 \times 10^{-4}$ & 39.7 & $2.2 \times 10^{-5}$ & 1.0 \\
\hline $\begin{array}{l}\text { Contami nated } \\
\text { Liner and Soi } 1\end{array}$ & Soil 1 & $8.6 \times 10^{-5}$ & 91.0 & $9.4 \times 10^{-6}$ & 1.0 \\
\hline Trash & Miscellaneous & $9.7 \times 10^{-4}$ & 25.0 & $3.9 \times 10^{-5}$ & 1.0 \\
\hline $\begin{array}{l}\text { Total Burial } \\
\text { Volume }\end{array}$ & & & 1090.3 & & \\
\hline
\end{tabular}


TABLE 5.3. Materials from DECON of Reference $U_{-6}$ Plant

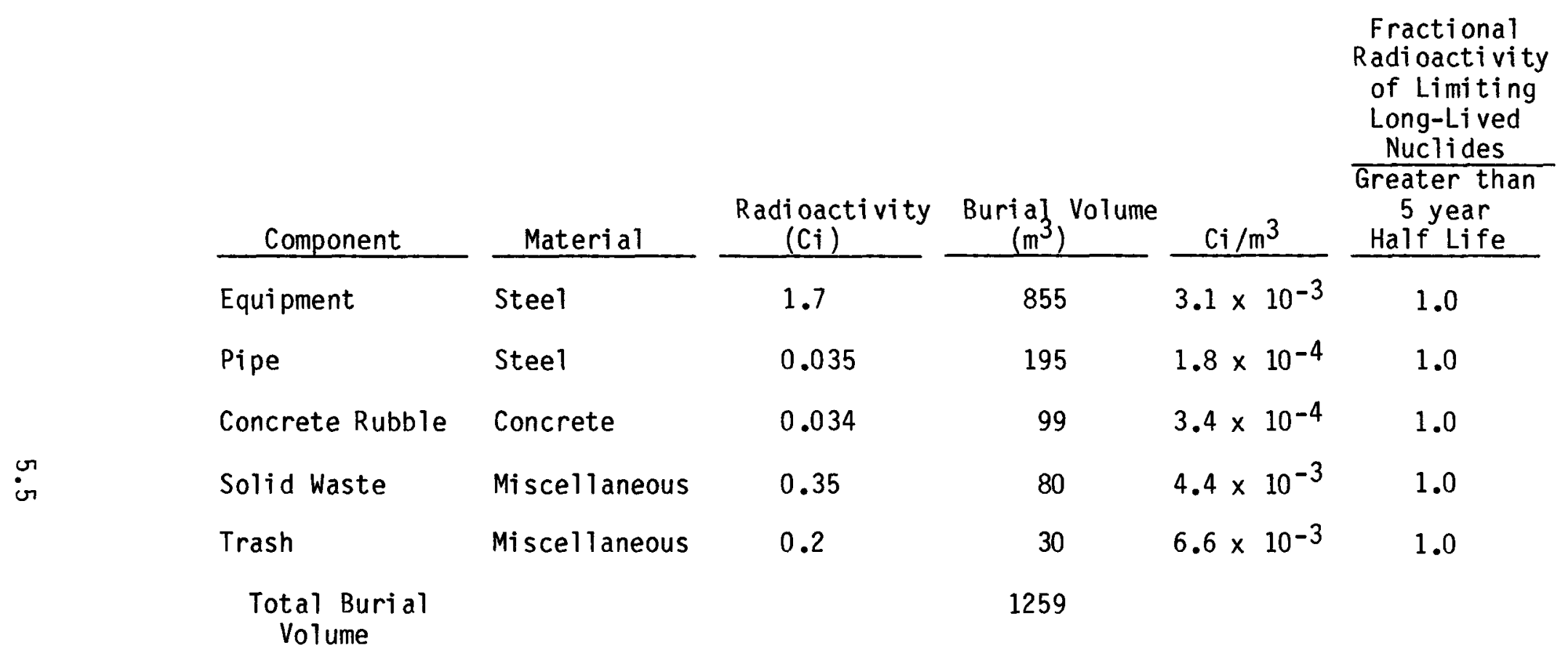




\subsection{CLASSIFICATION OF NUCLEAR FUEL CYCLE FACILITY DECOMMISSIONING WASTES}

A summary of waste class assignments for the radioactive wastes from conceptual decommissioning of the reference plants are given in this section. The burial volumes of the waste in each waste class are shown in the tables. Waste class assignments are based on waste characterization data for the reference plants summarized in Section 5 and on waste category definitions given in 10 CFR 61 and summarized in Tables 3.1 and 3.2 of this report.

Details of the waste class assignments for radioactive wastes from conceptual decommissioning of the reference MOX U-Fab and UF 6 plants are given in the following sections.

\subsection{MOX PLANT DECOMMISSIONING WASTES}

A summary of waste class assignments for the radioactive wastes from conceptual decommissioning of the reference MOX plant is given in Table 6.1. The actual volumes of waste in each waste class are shown in the table. Waste class assignments are based on waste characterization data for the reference MOX plant summarized in Section 5 and on waste category definitions given in 10 CFR 61 and summarized in Table 3.1 of this report.

Most of the radioactive waste from MOX plant decommissioning will have to be sent to interim storage. For the reference plant, approximately $11 \%$ of the waste from decommissioning (excluding the lagoon sludge) is estimated to be Class A waste. Approximately $89 \% \mathrm{~m}^{3}$ of waste (excluding the lagoon waste) is estimated to exceed the Class C limits of $10 \mathrm{CFR} 61$. The lagoon wastes are Class A waste.

\subsection{U-Fab PLANT DECOMMISSIONING WASTES}

A summary of waste class assignments for the radioactive wastes from conceptual decommissioning of the reference U-Fab plant is given in Table 6.2. the actual volumes of waste in each waste class are shown in the table. Waste class assignments are based on waste characterization data for the reference U-Fab plant summarized in Section 5 and on waste category definitions given in 10 CFR 61 and summarized in Table 3.1 of this report.

All of the radioactive waste from U-Fab plant decommissioning will be sent to low-level waste disposal. For the reference plant, all waste from decommissioning is estimated to be Class $A$ waste.

\subsection{UFF $_{6}$ PLANT DECOMMISSIONING WASTES}

A summary of waste class assignments for the radioactive wastes from conceptual decommissioning of the reference $U F_{6}$ plant is given in Table 6.3. 
Table 6.1. Waste Classifications of Materials From DECON of the Reference MOX PIant

\begin{tabular}{|c|c|c|c|c|c|c|c|}
\hline \multirow[b]{3}{*}{ Component } & \multirow[b]{3}{*}{$\begin{array}{c}\text { Burial } \\
\text { Volume } \\
\left(\mathrm{m}^{3}\right)\end{array}$} & \multirow{3}{*}{$\begin{array}{c}\text { Total } \\
\text { Specific } \\
\text { Activițy } \\
\left(\mathrm{Ci} / \mathrm{m}^{3}\right)\end{array}$} & \multicolumn{4}{|c|}{ Limiting Long-Lived Nuclides } & \multirow[b]{3}{*}{$\begin{array}{l}\text { Waste } \\
\text { Class }\end{array}$} \\
\hline & & & \multicolumn{2}{|c|}{$\begin{array}{l}\text { Fractional Specific } \\
\text { Activity }\left(\mathrm{Ci} / \mathrm{m}^{3}\right)\end{array}$} & \multicolumn{2}{|c|}{$\frac{\text { Specific Activity in } \mathrm{Ci} / \mathrm{g}}{\text { Greater Than }}$} & \\
\hline & & & $241 P_{u}$ & $\begin{array}{c}\text { Greater Than } \\
5 \text { Year } \\
\text { Half Life } \\
\end{array}$ & $241_{\mathrm{Pu}}$ & $\begin{array}{l}\text { Greater Than } \\
5 \text { Year } \\
\text { Malf Life } \\
\end{array}$ & \\
\hline Glove Boxes and Hoods & 134.8 & 99.7 & 0.17 & 99.5 & $1.5 \times 10^{-7}$ & $9.0 \times 10^{-5}$ & Interim Storage \\
\hline Tanks and Equipment & 108.2 & 37.9 & 0.06 & 37.8 & $5.4 \times 10^{-8}$ & $3.4 \times 10^{-5}$ & Interim Storage \\
\hline HEPA and Roughing Filter & 34.3 & 32.0 & 0.05 & 31.9 & $1.5 \times 10^{-7}$ & $1.0 \times 10^{-4}$ & Interim Storage \\
\hline Concrete Rubble & 20.0 & 48.9 & 0.08 & 48.8 & $6.7 \times 10^{-8}$ & $4.1 \times 10^{-5}$ & Interim Storage \\
\hline Solidified Decontamination liquids & 14.4 & 1631.7 & 2.8 & 1628.9 & $8.7 \times 10^{-7}$ & $5.1 \times 10^{-4}$ & Interim Storage \\
\hline Trash & 48.6 & $8.2 \times 10^{-3}$ & $1.4 \times 10^{-5}$ & $8.2 \times 10^{-3}$ & $1.7 \times 10^{-11}$ & $1.0 \times 10^{-8}$ & A \\
\hline Piping, Valves and Ductwork & 71.0 & 61.5 & 0.1 & 61.4 & $9.1 \times 10^{-8}$ & $5.6 \times 10^{-5}$ & Interim Storage \\
\hline Sewage Lagoon Sludge & 2930 & $1.7 \times 10^{-4}$ & $2.9 \times 10^{-7}$ & $1.7 \times 10^{-4}$ & $2.6 \times 10^{-13}$ & $1.5 \times 10^{-10}$ & A \\
\hline
\end{tabular}


Table 6.2. Waste Classifications of Materials From DECON of the Reference U-Fab Plant

\begin{tabular}{|c|c|c|c|c|c|}
\hline \multirow[b]{3}{*}{ Component } & & & \multicolumn{2}{|c|}{ Limiting Long-Lived Nuclides } & \multirow[b]{3}{*}{$\begin{array}{l}\text { Waste } \\
\text { Class } \\
\end{array}$} \\
\hline & & Total & $\begin{array}{l}\text { Fractional Specific } \\
\text { Activity }\left(\mathrm{C} i / \mathrm{m}^{3}\right)\end{array}$ & $\begin{array}{l}\text { Specific Activity } \\
\text { in } \mathrm{C} i / \mathrm{g}\end{array}$ & \\
\hline & $\begin{array}{l}\text { Burial } \\
\text { Volume } \\
\left(\mathrm{m}^{3}\right) \\
\end{array}$ & $\begin{array}{c}\text { Specific } \\
\text { Activity } \\
\left(\mathrm{Ci} / \mathrm{m}^{3}\right) \\
\end{array}$ & $\begin{array}{c}\text { Greater Than } \\
5 \text { Year } \\
\text { Half Life } \\
\end{array}$ & $\begin{array}{c}\text { Greater Than } \\
5 \text { Year } \\
\text { Half Life } \\
\end{array}$ & \\
\hline Hoods and Equipment & 764.4 & $1.2 \times 10^{-5}$ & $1.2 \times 10^{-5}$ & $1.1 \times 10^{-11}$ & A \\
\hline Pipe & 118.5 & $3.6 \times 10^{-6}$ & $3.6 \times 10^{-6}$ & $3.3 \times 10^{-12}$ & A \\
\hline Filter & 51.7 & $1.3 \times 10^{-5}$ & $1.3 \times 10^{-5}$ & $1.2 \times 10^{-11}$ & A \\
\hline Concrete Rubble & 39.7 & $2.2 \times 10^{-5}$ & $2.2 \times 10^{-5}$ & $2.0 \times 10^{-11}$ & A \\
\hline Contaminated Liners and Soil & 91.0 & $9.4 \times 10^{-6}$ & $9.4 \times 10^{-6}$ & $8.5 \times 10^{-12}$ & A \\
\hline Trash & 25.0 & $3.9 \times 10^{-5}$ & $3.9 \times 10^{-5}$ & $3.5 \times 10^{-11}$ & A \\
\hline
\end{tabular}


Table 6.3. Waste Classifications of Materials From DECON of the Reference UF 6 Plant

\begin{tabular}{|c|c|c|c|c|c|}
\hline \multirow[b]{4}{*}{ Component } & \multirow{4}{*}{$\begin{array}{c}\text { Burial } \\
\text { Volyme } \\
\left(\mathrm{m}^{3}\right)\end{array}$} & \multirow{4}{*}{$\begin{array}{c}\text { Total } \\
\text { Specific } \\
\text { Activitity } \\
\left(\mathrm{C} i / \mathrm{m}^{3}\right) \\
\end{array}$} & \multicolumn{2}{|c|}{ Limiting Long-Lived Nuclides } & \multirow[b]{4}{*}{$\begin{array}{l}\text { Waste } \\
\text { Class } \\
\end{array}$} \\
\hline & & & $\begin{array}{l}\text { Fractional Specific } \\
\text { Activity }\left(\mathrm{Ci} / \mathrm{m}^{3}\right)\end{array}$ & $\begin{array}{c}\text { Specific Activity } \\
\text { in } \mathrm{C} i / \mathrm{g}\end{array}$ & \\
\hline & & & Greater Than & Greater Than & \\
\hline & & & $\begin{array}{l}5 \text { Year } \\
\text { Half Life } \\
\end{array}$ & $\begin{array}{l}5 \text { Year } \\
\text { Half Life } \\
\end{array}$ & \\
\hline Equipment & 855 & $3.1 \times 10^{-3}$ & $3.1 \times 10^{-3}$ & $2.8 \times 10^{-9}$ & A \\
\hline Piping & 195 & $1.8 \times 10^{-4}$ & $1.8 \times 10^{-4}$ & $1.6 \times 10^{-10}$ & A \\
\hline Concrete Rubble & 99 & $3.4 \times 10^{-4}$ & $3.4 \times 10^{-4}$ & $3.1 \times 10^{-10}$ & A \\
\hline Solid Waste & 80 & $4.4 \times 10^{-3}$ & $4.4 \times 10^{-3}$ & $4.0 \times 10^{-9}$ & A \\
\hline Trash & 30 & $6.6 \times 10^{-3}$ & $6.6 \times 10^{-3}$ & $6.0 \times 10^{-9}$ & $A$ \\
\hline
\end{tabular}


The actual volumes of waste in each waste class are shown in the table. Waste class assignments are based on waste characterization data for the reference UF $_{6}$ plant summarized in Section 5 and on waste category definitions given in 10 CFR 61 and summarized in Table 3.1 of this report.

All of the radioactive waste from plant decommissioning will be sent to low-level waste disposal. For the reference plant, all of the waste from decommissioning is estimated to be Class A waste. 


\subsection{CONCLUSIONS}

The nuclear wastes from conceptual decommissioning of a reference fuel cycle facility plants are classified, in this addendum, in terms of the waste classes specified in 10 CFR 61 . The results are tabulated in Table $6.1,6.2$ and 6.3 of Section 6 .

Most of the nuclear waste from decommissioning the MOX plant (except for the lagoon wastes) is considered to have radionuclide concentrations that exceed Class $C$ waste and will have to be placed in interim storage. All waste from the Ul-Fab and UF $U_{6}$ plants is classified as Class $A$ and will be disposed of in shallow-land disposal. To be acceptable for shallow-land disposal, Class A waste must meet the minimum packaging and waste form requirements given in paragraph $61.56(a)$ of 10 CFR. The waste processing and packaging methods described in the reference study (Reference 1) provide sufficient protection to permit the handling and disposal of these wastes at a licensed shallow-land disposal site without further packaging requirements.

Class $C$ waste must meet the stability requirements of 10 CFR $61.56(\mathrm{~b})$ and must also be disposed of by a burial site operator using methods that provide additional protection against inadvertent intrusion into the burial ground. Class $C$ waste must be buried so that the top of the waste is a minimum of 5 meters below the top surface cover, or must be placed within intruder barriers that are designed to protect against an inadvertent intrusion for at least 500 years. The disposal costs for Class $C$ waste could be significantly higher than the disposal costs for $\mathrm{Cl}$ ass $\mathrm{A}$ and $\mathrm{Cl}$ ass $\mathrm{B}$ wastes. An estimate of these higher costs is beyond the scope of this report and is not covered here.

Nuclear waste that exceeds Class C limits according to the provisions of 10 CFR 61 is not acceptable for routine near-surface disposal. The licensee is required to safely store this waste until a specific determination can be made on its disposition. Onsite storage of decommissioning waste would prevent termination of the nuclear license and release of the site until the waste was subsequently removed to an offsite disposal facility. The prospect of onsite storage of nuclear waste. for a protracted period could therefore affect the choice of an alternative to decommission the plant. 


\subsection{REFERENCES}

1. C. E. Jenkins, E. S. Murphy, and K. J. Schneider, Technology, Safety and Costs of Decommissioning a Reference Small Mixed-0xide Fuel Fabrication PTant, NIIREG/CR-0129, VoTs. 1 and 2, Pacific Northwest Laboratory for U.S. Nuclear Regulatory Commission, February 1979.

2. H. K. Elder and D. E. Blahnik, Technology, Safety and Costs of Decommissioning a Reference Uranium FueT Fabrication Plant, NITREG/CR-1266, Vols. 1 and 2, Pacific Northwest Laboratory for U.S. Nuclear Regulatory Commission, October 1980.

3. H. K. Elder, Technology, Safety and Costs of Decommissiuning a Reference Uraniunl HexafTuoride Conversion Plant. NUREG/CR-1757, Pacific Northwest Laboratory for U.S. Nuclear Regulatory Commission, October 1981.

4. "Licensing Requirements for the Land Disposal of Radioactive Waste," Federal Register, Vol. 47, No. 248, December 27, 1982, pp. 57446-57482.

5. Final Waste Classification and Waste Form Technical Position Papers, U.S. Nuclear Regulatory Commission, Washington, D.C., May 11, 1983.

6. G. D. Calkins, Plan for Reevaluation of NRC Policy on Decommissioning of Nuclear Facilities, NIJREG-0476, Revision 1, Supplement 1, II.S. Nuclear Regulatory Commission, Washington, D.C., August 1980.

7. Draft Generic Environmental Impact Statement on Decommissioning of Nuclear Facilities, NUREG-0586, II.S. Nuclear Regulatory Commission, Washington, D.C., January 1981. 


\section{NUREGLCR-4519}

PNL-5586

2 Lesve Dionk

3 TITLE AND SUBTITLE

Technology, Safety and Costs of Decommissioning Nuclear

Fuel Cycle Facilities Classification of Decommissioning

Waste

H. K. Elder

5 DATE AEPORT COMPLETED

MONTH TYEAR

August

7 DATE REPORT ISSUED

MONTH

May

1985

9 PAOJECT/TASK/WOAK UNIT NUMBEA

8 PERFORMING ORGANIZATION NAME ANO MAILING ADDRESS (Include Zip Code)

Pacific Northwest Laboratory

P.0. Box 999

Richland, Washington 99352

B2117

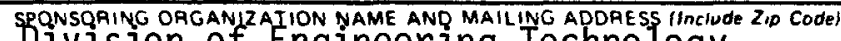

Division of Engineering Technology

Office of Nuclear Regulatory Research

U. S. Nuclear Regulatory Commission

Washington, D. C. 20555

Technical

12b PERIOD COVERED (Inclusive dotes)

13 SUPPLEMENTARY NOTES

14 ABSTRACT (200 words or less)

The radioactive wastes expected to result from decommissioning nuclear fuel cycle facilities are reviewed and classified in accordance with 10 CFR 61 .

Most of the wastes from the MOX plant (exclusive of the lagoon wastes) will require interim storage (11\% Class A $49 \mathrm{~m}^{3} ; 89 \%$ interim storage, $\left.383 \mathrm{~m}^{3}\right)$. All of the wastes from the U-Fab and UF 6 plants are designated as Class A waste (U-Fab $1090 \mathrm{~m}^{3}$, UF$\left._{6} 1259 \mathrm{M}^{3}\right)$.

Decommissioning Waste

Waste Classification

Fuel Cycle

\begin{tabular}{|c|c|}
\hline $\begin{array}{l}17 \text { SECUAITY CLASSIFICATION } \\
\text { IThis reportI } \\
\text { unclassified }\end{array}$ & 18 NUMBEP OF PAGES \\
\hline $\begin{array}{l}19 \text { SECURITY CLASSIFICATION } \\
\text { IThis Dagel } \\
\text { unclassified }\end{array}$ & $\begin{array}{l}20 \text { PAICE } \\
\text { S }\end{array}$ \\
\hline
\end{tabular}


This report was prepared as an account of work sponsored by an agency of the United States Government. Neither the United States Government nor any agency thereof. or any of their employees, makes any warranty. expressed or implied. or assumes any legal liability of re. sponsibility for any third party's use. or the results of such use. of any information, apparatus. product or process disclosed in this report, or represents that its use by such. third party would not infringe privately owned rights.

\section{Availability of Reference Materials Cited in NRC Publications}

Most documents cited in NRC publications will be available from one of the following sources:

1. The NRC Public Document Room, 1717 H Street, N.W. Washington. DC 20555

2. The NRC/GPO Sales Program, U.S. Nuclear Regulatory Commission, Washington, DC 20555

3. The National Technical information Service, Springfield..VA 22161

Although the listing that follows represents the majority of documents cited in NRC publications. it is not intended to be exhaustive.

Referenced documents available for inspection and copying for a fee from the NRC Public Document Room include NRC correspondence and ir.ternal NRC memoranda; NRC Office of Inspection and Enforcement bulletins, circulars, information notices, inspection and investigation notices: Licensee Event Reports: vendor reports and correspondence; Commission papers; and applicant and licensee documents and correspondence.

The following documents in the NUREG series are available for purchase from the NRC/GPO Sales Program: formal NRC staff and contractor reports. NRC-sponsored conference proceedings, and NRC booklets and brochures. Also available are Regulatory Guides, NAC regulations in the Code of Federal Regulations, and Nuclear Regulatory Commission Issuances.

Documents available from the National Technical information Service include NUREG series reports and technical reports prepared by other federal agencies and reports prepared by the Atomic Energy Commission, forerunner agency to the Nuclear Regulatory Commission.

Documents available from public and special technical libraries include all open literature iterns. such as books. journal and periodical articles, and transactions. Federal Register notices. federal and state legislation. and congressional reports can usually be obtained from these libraries.

Documents such as theses, dissertations, foreign reports and translations, and non.NRC conference proceedings are available for purchase trom the organization sponsoring the publication cited.

Single copies of NRC dratt reports are available free upon written request to the Division of Technical Information and Document Control, U.S. Nuclear Regulatory Commission. Washington. DC 20555.

Copies of industry codes and standards used in a substantive manner in the NRC regulatory process are maintained at the NRC Library. 7920 Norlolk Avenue. Bethesda. Maryland, and are available there for reference use by, the public. Codes and standards are usually copyrighted and may be purchased from the originating organization or, if they are American National Standards. from the American National Standards Institute. 1430 Broadway. New York. NY 10018. 